\title{
FROM THE ORDER OF THE FRANKS TO THE WORLD OF AMBROSE: THE VITA ADALHARDI AND THE EPITAPHIUM ARSENII COMPARED
}

\author{
Mayke de Jong
}

$\mathrm{H}$ aving just (in 2018) completed a book with Paschasius Radbertus's Epitaphium Arsenii at its heart, ${ }^{1}$ I realize that in all the years I worked on this text I never gave any thought to ethnic identity - unsurprisingly, for the Epitaphium does not contain a single reference to the most obvious ethnic identification in a funeral oration for one of Charlemagne's cousins: Franks or Frankishness. ${ }^{2}$ My growing familiarity with Radbert's funeral oration or epitaph for Wala, abbot of Corbie, rendered this absence all the more invisible, until recently, when it finally dawned on me how different Radbert's Vita Adalhardi is in this respect. This tribute to Wala's half-brother and predecessor, Abbot Adalhard of Corbie, was written shortly after the latter's death

${ }^{1}$ De Jong, Epitaph for an Era. The Epitaphium Arsenii is cited after Dümmler's edition of the one mid-ninth-century manuscript (BnF, MS lat. 13909). On the Epitaphium, see above all Von Moos, Consolatio, I, 137-46 and II, 97-106; Ganz, Corbie, pp. 82-87, 103-20; Ganz, 'Epitaphium'; more recently, Verri, 'Il libro primo'; De Jong, Penitential State, pp. 102-11, 197-207; Booker, Past Convictions, pp. 42-50; De Jong, 'Becoming Jeremiah'; De Jong, 'Resources'; Booker, 'Hypocrisy'; Kempshall, Rhetoric, pp. 196-208. See now also the new annotated translation of the text by Justin Lake and myself: Confronting Crisis in the Carolingian Empire.

2 On repertories of identification, see Pohl, 'Introduction: Strategies of Identification', pp. 32-38; see also Pohl, 'Creating Cultural Resources'.

Mayke de Jong is Professor Emeritus of Medieval History, Utrecht University

Historiography and Identity III: Carolingian Approaches, ed. by Rutger Kramer, Helmut Reimitz, and Graeme Ward, CELAMA 29 (Turnhout: Brepols, 2021), pp. 39-63 
in January $826 .^{3}$ Despite its title, which is original, this earlier work was also conceived of as an 'epitaph' or funeral oration. Like the Epitaphium Arsenii it was inspired by late antique examples, especially those provided by Ambrose of Milan, yet in the Life of Adalhard, the protagonist's Frankishness is a prominent feature and a matter of pride. This is not just emphasized in the context of Adalhard's illustrious origins, albeit with the assurance that he was actually a citizen of Jerusalem. ${ }^{4}$ The great man also represents a right kind of social and religious order that was characterized as essentially Frankish. When Adalhard had returned from exile in 821, having been sent off upon Louis's accession in 814 to the island of Noirmoutier, it seemed as if 'a new order of the Franks was reborn, and the sun of justice rose from the east.'.

Roughly ten years later, not long after Wala’s death in August 836, Radbert embarked on the first book of his Epitaphium Arsenii, a funeral oration for Arsenius, as Wala was called by his monks. This first part concentrates on the great man's many virtues, displayed first as a youth at Charlemagne's court, then as a monastic leader in Corbie, and finally as a dispenser of justice in Italy in the mid-820s. The second book was added about two decades later, in the mid850 s, and deals with the rebellions against Louis the Pious and Wala's subsequent exile, with a marked focus on the first rebellion of 830. It introduces a new repertoire of identification derived from what I have loosely labelled 'the world of Ambrose': an imagined community defined by the historiography of the late antique Christian empire. The following is an attempt to make some sense of this disappearance of Frankishness, and to suggest a possible context for this change of perspective.

3 The best text is still the one in Migne, Patrologia latina, Cxx, cols 1507-82; this is based on Dom Jean Mabillon's edition in Acta sanctorum Ordinis Sancti Benedicti, Iv.1 (1677), 308-44. The oldest manuscript is from Corbie: BnF, MS lat. 18296 with the Vita Adalhardi (fols 36-67) as a distinct codicological unit from the third quarter of the ninth century; see Ganz, Corbie, p. 145; Bischoff, Katalog, III, no. 5047, p. 231; for a fuller discussion of the text, see Berschin, Biographie, III, 309-18; Von Moos, Consolatio, I, 137-46; Ganz, Corbie, pp. 103-12. Von der Nahmer, 'Die Bibel im Adalhardsleben'; Verri, 'L'arte di ritratto'; De Jong, Epitaph for an Era, pp. 76-86.

${ }^{4}$ Paschasius Radbertus, Vita Adalhardi, ed. by Migne, 56, col. 1537A-B.

5 Paschasius Radbertus, Vita Adalhardi, ed. by Migne, 52, col. 1535B: 'videtur demum novus renasci Francorum ordo, et aurora justitiae quasi ab ortu surgere'. 


\section{Before and After 829?}

My point of departure is Helmut Reimitz's recent study of the development of Frankish identity in historiographical sources. Reimitz takes a wide-ranging view, from the mid-sixth to the mid-ninth centuries. ${ }^{6}$ The last chapter, entitled 'before and after 829 ' discusses the breakdown of a historiographical consensus that was exemplified by the Royal Frankish Annals. Whereas its earlier sections are characterized by a triumphalist affirmation of Frankishness, this was gradually toned down, to make room for a more inclusive politics of identity with a shared Christianity at its heart. The retreat of Frankish exclusivity becomes visible already in the late 780 s, when religious reform and correctio came to define Charlemagne's rulership, and even more so in the revised version of the Annals for the years 741-801, which may well have originated during the reign of Louis the Pious. In the court annals produced since Louis succeeded in 814 the populus christianus had become the primary focus of integration. Court historians developed a broad consensus characterized by what Reimitz calls 'a restrained use of the name of the Franks as one important group in a Christian regnum whose imperial structure was also emphasised in quotations from the Roman classics.?

As Reimitz explains, this consensus was fragile. After the entry for 829 the Royal Frankish Annals break off abruptly; this last bit of the text starts with the ominous damage to the roof of the palace chapel in Aachen, due to an earthquake and storm shortly before Easter, and ends with Louis's return from the autumnal hunt in Frankfurt to Aachen where he celebrated the feasts of St Martin and St Andrew as well as Christmas. ${ }^{8}$ The section of the court annals from 814 to 829 was widely disseminated and became an authoritative building block for later historical compendia and narratives, such as the Astronomer's Life of Louis. ${ }^{9}$ Beyond 829, however, the earlier consensus gave way to more fragmented and contested views of recent history. There are plenty of continuations, such as the Annals of St Bertin, but already in their narrative of the rebellions of the 830s these texts diverge widely, and so do other accounts of the

${ }^{6}$ Reimitz, History; see also Reimitz, 'Nomen Francorum obscuratum'.

${ }^{7}$ Reimitz, History, p. 420.

8 Annales regni Francorum, ed. by Kurze, s.a. 829, pp. 176-78.

9 Astronomer, Vita Hludowici imperatoris, ed. by Tremp, relies on the Annales regni Francorum from 23, p. 352 (= Annales regni Francorum, ed. by Kurze, s.a. 814, p. 140) up to 44 (= Annales regni Francorum, s.a. 829, pp. 177-78); on this text, see most recently Ganz, 'The Astronomer's Life'. 
further reign of Louis and beyond, be they histories or biographies. In none of these does Frankishness play a key role. Reimitz suggests that this signals a crisis of Frankish identity, and reminds us of Agobard of Lyon's fiery treatises, in which the archbishop maintained that scandal at the palace had brought shame on the Franks and obscured their name. Agobard's particular brand of polemics was exceptional, but, in Reimitz's view, 'his negative view of Frankish identity actually reflects the general trend in the Carolingian Empire. ${ }^{10}$ Only towards the end of the ninth century and thereafter pride in being Frankish made a come-back, particularly in West Francia and the French kingdom. These later authors tapped into the affirmative view of Frankish identity of the older, non-revised version of the Royal Frankish Annals, while compilers in the East Frankish Empire tended to turn to the revised annals and their restrained use of Frankishness. ${ }^{11}$

This is just a brief summary of Reimitz's views on 'before and after 829 '. He and I already discussed this issue in 2005-06 when we were working closely together. ${ }^{12}$ At the time I was none too keen on the idea that the sudden break of the Annals after 829 had wider implications, even with regard to the selfperception of a palace-connected elite. I was writing The Penitential State and intended to show that the moralization of political discourse had only developed gradually, first during Charlemagne's reign and then under his son Louis; the older grand narrative of the weak and monkish son of a mighty and essentially secular father had to go, and so had the tendency to see the rebellions of the early 830s as the beginning of the end of the Carolingian Empire. In 814 a new emperor assumed a royal religious authority that was already well established, and which survived the two rebellions against Louis. If anything, the 'sacred palace' gained sharper contours after having been contested so fiercely during these two short-lived revolts. ${ }^{13}$ In other words, I was writing about continuity and trying to put the so-called crisis into this perspective, while Reimitz had a clear sense that the sudden ending of the Royal Frankish Annals after 829 was caused by the kind of upheaval that was anything but random or ephemeral.

By now I think Helmut Reimitz did have a point, even though to some extent, 'before and after 829 ' means comparing apples and oranges. The rebellions against

${ }^{10}$ Reimitz, History, p. 435.

11 Reimitz, History, pp. 442-43.

12 At the Netherlands Institute for Advanced Study in Wassenaar, in the thematic group on Carolingian identities of 2005-06 (consisting of Rosamond McKitterick, David Ganz, Els Rose, Helmut Reimitz, and myself).

${ }^{13}$ De Jong, 'Sacrum palatium'. 
Louis in the early 830 s and the struggle for succession after his death in 840 generated so much articulated reflection, by way of historiography, biography, and other genres, that the more modest corpus produced before 829 may look unified simply by default. All the same, as Rutger Kramer has pointed out recently, the first decade of Louis's reign was characterized by great expectations concerning the possibilities of emendatio and correctio of an empire that largely overlapped with notions of the ecclesia. With hindsight, the optimism and energy with which the emperor took his religious responsibilities in hand is easily obscured. ${ }^{14} \mathrm{Of}$ course such positivity did not disappear overnight in 829 . A particularly strident statement about Frankish imperial rule was produced in this very year by Hrabanus Maurus, abbot of Fulda, in the context of his struggle with the Saxon monk Gottschalk who denied the validity of Frankish witnesses at his oblation to Fulda. Hrabanus countered that it was the Franks who had conquered and converted the Saxons, so theirs was the superior testimony. Just as once all the peoples (gentes) had enjoyed the dignity of Roman citizenship, they were now submitted to the Franks, who were the heirs to this lofty Roman imperial rule. ${ }^{15}$ Similarly, in the early 820s Agobard spoke out in favour of imposing a lex Francorum on the entire empire. ${ }^{16}$ Both Hrabanus and Agobard embedded these views in a Pauline vision of community in which the ecclesia transcended the divide between all the gentes, yet they also sang the praises of an emphatically Frankish empire; moreover, they did so in treatises destined for Louis and his court, trying to convince an audience they expected to be receptive to their reasoning.

\section{Restoring the Order of the Franks: The Vita Adalhardi}

Strategies of persuasion directed at Louis's court are relevant for a better understanding of the Vita Adalhardi. In this epitaph for his beloved elder mentor, Radbert painted a portrait of the saintly Adalhard in which he hailed 'Tullius, the king of rhetoric' (Cicero), ${ }^{17}$ and sought to impress his readers by making it clear that he followed rhetorical rules of charakterismos. One of the aims of

${ }^{14}$ Kramer, Rethinking Authority, p. 225.

${ }^{15}$ Hrabanus Maurus, De oblatione puerorum, ed. by Migne, col. 432A-C; De Jong, 'State of the Church', pp. 25-26; Patzold, 'Hraban'.

16 Reimitz, History, p. 434; Agobard, Adversus legem Gundobadi, ed. by Van Acker, 3, pp. 20-21; ed. by Dümmler, 3, p. 159.

17 Paschasius Radbertus, Vita Adalhardi, ed. by Migne, 20, col. 1518C: 'Scribit namque Tullius, rex eloquentiae Latinae, in libro secundo de inventione rhetoricae artis'; see also Paschasius Radbertus, Expositio in Mattheum, ed. by Paulus, prologue, I, 6, 1. 158. 
all this literary brilliance was to pave the way for his patron Wala as Adalhard's successor, not just to the abbacy of Corbie, but also of Corvey, Corbie's 'daughter' in Saxony. Hence, Wala is depicted as a Joshua who is waiting in the wings, ready to defend Corbie against the onslaughts of the Amalekites (Exodus 17.8-16). ${ }^{18}$ This suggests that Radbert was writing at a time when Wala's leadership of Corbie was not yet a foregone conclusion. Clearly some monks were highly critical of Wala's prominent position at Louis's court, ${ }^{19}$ and the emperor himself seems to have taken some persuading as well: with some pride, Radbert made it clear in his Epitaph for Arsenius that he himself had been delegated by his community to plead the case for Wala's succession at the palace. ${ }^{20}$

First of all the Vita Adalhardi is a lament for the great man's death, and a celebration of his many virtues, yet it is also a timely work with an immediate purpose. Although Adalhard is the chief recipient of Radbert's fulsome praise, this is also extended to his siblings Wala, Gundrada, Bernarius, and Theodrada. ${ }^{21}$ All suffered some form of exile or displacement when Louis ascended to the throne, with the exception of Theodrada, abbess of Notre Dame in Soissons, the convent where the orphan Radbert was brought up. ${ }^{22}$ In his Life Adalhard is introduced as the scion of a royal family, the nephew of King Pippin and the first cousin of Charles Augustus, 'raised at the palace in prudence with youths from the entire world, entrusted to masters together with the ruler of the earth.'23 This imperial imagery is evoked at the start of a well-known story which portrays Adalhard as a paragon of Frankish virtue. Although only a 'novice of the palace' the young courtier did not countenance Charlemagne's repudiation of the daughter of Desiderius, king of the Lombards. The king had married only recently, supported by 'the oaths of some of the Franks', but had married a new queen with whom Adalhard could not in any way be associated. His main objection, however, was that this unlawful marriage would mean that 'some of the Franks' (nonnulli Francorum) would perjure themselves. He

18 Paschasius Radbertus, Vita Adalhardi, ed. by Migne, 86, cols 1551D-52A. The standard biography of Wala is still Weinrich, Wala, which relies heavily on the Epitaphium Arsenii; on Adalhard, the first port of call remains Kasten, Adalhard.

${ }^{19}$ Paschasius Radbertus, Epitaphium Arsenii, ed. by Dümmler, II.5, p. 65.

${ }^{20}$ Paschasius Radbertus, Epitaphium Arsenii, ed. by Dümmler, I.11, p. 39.

${ }^{21}$ Paschasius Radbertus, Vita Adalhardi, ed. by Migne, 32-34, cols 1526B-27D.

22 Paschasius Radbertus, Vita Adalhardi, ed. by Migne, 35-36, col. 1528A-D.

23 Paschasius Radbertus, Vita Adalhardi, ed. by Migne, 7, col. 1511B: 'Qui cum esset regali prosapia, Pippini magni regis nepos, Caroli consobrinus Augusti, inter palatii tirocinia omni mundi prudentia eruditus, una cum terrarum principe magistris adhibitus'. 
resisted strenuously, for the laws of Christ should prevail over those of kinship, which only induced giving in to the flesh. Keeping one's oath was at the heart of the leges Christi, for which Adalhard stood firm, like a latter-day John the Baptist had, so he entered Corbie as a monk.

The narrative of Adalhard's entry into monastic life follows the hagiographical topos of the young saint who valiantly leaves the world, despite resistance on the part of parents or rulers. ${ }^{24}$ Yet here and elsewhere in the text, Adalhard is presented as the guardian of Frankishness, of the kind defined by the concept of Christian faithfulness (fides) and cemented by oaths. He persistently combated perjury and always kept his promises. 'Recently', so presumably not long before his death in January 826, Adalhard had admonished the Emperor Lothar on the importance of fides among men and the inviolability of a Christian oath sworn truthfully; a violation would imply contempt, not of man, but of God 'as a witness and my truth. ${ }^{25}$ To his relentless pursuit of justice, Francia could testify, and all the lands submitted to his authority, Italy in particular, for he became the young King Pippin's chief counsellor and support. ${ }^{26}$ This elicited a story about Adalhard's first meeting with Pope Leo III, which is obviously anecdotal, but all the more important for Radbert's underlining of typically Frankish virtues in the Vita Adalhardi:

When strong with virtue, [yet] meek and mild, he arrived in the territory of the Romans, where at the time the Lord Leo was the apostolic pontiff, he was received with the kind of familiar friendship that none of the Franks before him had yet received. Hence, some of ours related that he [Leo] spoke to the other in a joking mood. 'Frank', he said, 'you should know that if I find you different from whom I believe you to be, no other Frank need to come here to whom I need to lend any credence. From this it transpires clearly how much authority this man had, whose absence/trustworthiness would prove the whole people of the Franks was not to be believed, but whose steadfastness [of faith would prove] they were to be [believed]. ${ }^{27}$

${ }^{24}$ De Jong, Epitaph for an Era, pp. 22-23; for an in-depth investigation of the historical context, see Nelson, 'Making a Difference'.

25 Paschasius Radbertus, Vita Adalhardi, ed. by Migne, 18, col. 1518A: 'quantum valere debeat foedus Christiani in veritate promissum? non te decipiat aliquis, obsecro, inquit, imperator, quia fides cum contra aliquem violatur, non homo, sed Deus testis et veritas mea contemnitur'.

${ }^{26}$ Paschasius Radbertus, Vita Adalhardi, ed. by Migne, 16, col. 1517A. Kasten, Adalhard, pp. 42-47 thinks this episode should be situated in the period between 781 and 790 but concludes that the information is only 'schattenhaft'.

27 Paschasius Radbertus, Vita Adalhardi, ed. by Migne, 17, col. 1517D: 'Atque ita virtute validus mitis et mansuetus Romanorum pervenit ad fines, ubi a domno Leone tunc temporis apostolico, tanto familiaritatis officio est susceptus, ut neminem constiterit Francorum antea 
The Adalhard of Radbert's Life was above all an intrepid teller of truth to power in the best tradition of the Old Testament prophets. ${ }^{28}$ This anecdote contributes to this image, yet it also conveys Adalhard's easy familiarity with Rome and its pontiff, and even more so the message that the reputation of the Franks as a trustworthy people (genus) depended on men of his calibre. This mild yet forceful monk of illustrious birth was the embodiment of Frankish fides in the distant and foreign world that was Italy, at least for Radbert who had never ventured there. And this is by no means the only emphatic affirmation of Adalhard's Frankishness. There is an intriguing remark about the five siblings, who all sprang from the seed of this one man (Bernard, son of Charles Martel). The emperor (Charlemagne) had availed himself of the familiar counsel of three of them, so together, this 'stable square' had ruled the empire of the Franks and furthered the well-being of the commonwealth. ${ }^{29}$ Judging by the Vita Adalhardi, no assumptions can be made about Charlemagne's three counsellors being the males of the family. After all, it was Gundrada, not Bernarius, who was portrayed as a courtier.

Louis's accession to the throne in 814 put a temporary end to this stability, yet with Adalhard's return from exile in 821 and thanks to his tireless labour, an 'order of the Franks' was reborn and justice was restored. Now that the speaker of truth was back, it was clear how all had been kept in a state of lethargy. Radbert's depiction of Louis's conciliatory penance in Attigny in 822 is scathing, and easily equals his polemical pronouncements about the emperor in the second book of the Epitaphium Arsenii:

The glorious emperor himself undertook a public penance because of his many sins. He who as it were by royal haughtiness had been his own worst tempter was made the humblest of all, so those whose eyes he had offended by sin would be healed

suscepisse. Unde nostrorum quidam narrant sibi jocoso dixisse animo: "France, inquit, sciendo scias, quia si te aliud invenero quam te credo, non ultra necesse est Francorum aliquem huc venire cui credere debeam." Quo profecto patet quantum pondus habuerit idem vir, cujus evacuatio fidei Francorum genus omne probaverit non credendum, cujusve firmitatis fuerit'. I thank Justin Lake for his help with the puzzling final part-sentence; the only way to make sense of it is to read firmitatis as firmitas, equivalent to the noun evacuatio, yet the ninth-century manuscript (BnF, MS lat. 18296, fol. $42^{v}$ ) has firmitatis. I assume that the copyist was influenced by the preceding relative pronoun 'cuius'.

${ }^{28}$ De Jong, Penitential State, pp. 112-22; De Jong, Epitaph for an Era, pp. 125-29; Van Renswoude, Rhetoric of Free Speech, pp. 216-19.

29 Paschasius Radbertus, Vita Adalhardi, ed. by Migne, 32, col. 1526A-B: 'Erant igitur quinque unius viri semine propagati: quorum trium imperator Augustus familiari usus consilio, una secum fundabili quadratura Francorum imperium satis admodum dispositum regebat reipublicae augmentatum'. 
by a royal satisfaction. Doubtless all were particularly intent on his willingness and clearly observed his unwillingness. ${ }^{30}$

Only Adalhard's presence and his clarity of vision could cure Louis's court from its blindness. This in turn enabled the revival of the ordo Francorum that had prevailed under the august emperor, Charles. Repeatedly Radbert suggests that Adalhard and his siblings, rather than the ruling emperor, were the living representation of this order. In Vita Adalhardi they are senior members of this royal prosapia, with a superior claim to Frankish excellence. It is worth rereading the story about the repudiation of Desiderius's daughter in this light. Adalhard's moral indignation was not just a matter of the perjury of some Franks, but also made it impossible for him to serve Charles's next queen. This queen, who allegedly lacked legitimacy given her husband's prior union, was Hildegard, the mother of Louis the Pious. In 826 when Radbert wrote his Vita Adalhardi, these dark intimations concerning Hildegard may have mattered more than the actual fate of Desiderius's daughter half a century earlier. Even more recent was the memory of the injustice inflicted by Hildegard's son on Adalhard and his illustrious siblings.

Having completed his narrative of exile and return, Radbert asserts that Adalhard, a member of a most eminent family of Franks, nonetheless belonged to the heavenly Jerusalem. 'Although he was born from the most noble family of the noble Franks, as I said before, he was eventually adopted as a son by God, through the fatherland of Christ. ${ }^{31}$ Apart from reassuring his readers that Adalhard was part of the monastery rather than the court, this once more stresses the great man's eminent progeny, as well as his quintessential Frankishness. There was nothing restrained about this. In the Vita Adalhardi Radbert consistently refers to the Franks, plural. As a collective, Franci still counted for something in

${ }^{30}$ Paschasius Radbertus, Vita Adalhardi, ed. by Migne, 51, cols 1534D-35A: 'Quid plura? ipse gloriosus imperator publicam exnonnullis suis reatibus poenitentiam suscipiens, factus est omnium humillimus, qui quasi regali elatione sibi pessimus persuasor fuerat: ut quorum oculi offenderant in delicto, satisfactione regia sanarentur; praesertim quod ejus velle cunctos considerare, ejusque nolle conspicere manifestum non ambigitur. Sed nisi reversus esset Veritatis assertor, interea minime paruisset, quo lethargico spiritu premerentur. Unde etiam matura senectus caecitatis eorum vulnus salubri Christi antidoto mederi persuadendo curabat'. See De Jong, Penitential State, pp. 126-27; De Jong, Epitaph for an Era, pp. 103-06.

${ }^{31}$ Paschasius Radbertus, Vita Adalhardi, ed. by Migne, 56, col. 1537A-B: 'Natione autem, quod cunctis liquet, Francorum erat ex summorum genere; sed renatus in Christo, ubi et spiritu versabatur, totus natione coelestis omnibus renitebat. Unde et illi patria, quamvis hic carne natus esset, coelestis illa Hierusalem juxta Apostolum fuisse non dubitatur, per eum qui nos jam spe consedere fecit in coelestibus. Genere quidem nobilium nobilissimus Francorum, ut paulo ante praemisi, prosapia ortus, sed demum per Christi patriam Deo in filium est adoptatus'. 
Radbert's mind, and presumably also for those he sought to persuade of the excellence of Adalhard as an abbot, and Wala as his successor.

\section{Saxon Identities: The Epitaphium's First Book}

Wala died in August 836 in Italy. Together with others he had followed Louis's son Lothar south in 834, once the second rebellion against the emperor had failed, and together with them Wala succumbed two years later to an Italian epidemic. Lothar, who would survive until 855 , had made his loyal and by then elderly counsellor abbot of Bobbio, a monastery founded in 614 by Columbanus, another exile from Francia. ${ }^{32}$ Except for some possible adaptation at the very beginning and end, the Epitaphium's first book was written in the years directly after Wala's death. ${ }^{33}$ In this dialogue between the narrator Pascasius (a transparent alias for the author) and two fellow monks, the participants in this conversation about Arsenius create a world in which they had to hold their tongues, now that Wala's enemies had prevailed. The time would come when the truth about their beloved abbot and his motives could be spoken openly, but for the time being, silence and discretion were in order. Hence, explicit references to Wala's leading role in the revolts of 830 and 833 and his subsequent exile are largely avoided. Instead, Radbert concentrates on an earlier phase of Wala's life, roughly from the time when he was a youth at Charlemagne's court to the years 822-25 when he was Lothar's mentor and deputy in the kingdom of Italy. The discussants' conversation revolves around their grief at the loss of their beloved abbot, yet it also conveys a sense of desertion, and yields the impression that some monks of Corbie were angry about Wala's departure and, moreover, about his leadership of another monastic community.

Another likely grievance against the controversial abbot was the loss of Corbie's 'daughter' Corvey, founded by Adalhard and Wala in Saxony in 822. A substantial section of the first book contains the narrative of this joint foundation, and ignores the fact that this enterprise succeeded with considerable support from Louis the Pious. Wala had succeeded his brother as abbot of Corbie and Corvey; Radbert celebrated the unbreakable bond between the two communities in an elegiac poem he added to his Vita Adalhardi. ${ }^{34}$ Yet

${ }^{32}$ For the comparison between Columbanus and Wala, both driven south by the vengeance of a woman (Brunhild and Judith respectively), see Paschasius Radbertus, Epitaphium Arsenii, ed. by Dümmler, II.21, p. 92.

\footnotetext{
33 De Jong, Epitaph for an Era, pp. 7-11.

${ }^{34}$ De Jong, Epitaph for an Era, pp. 48-52.
} 
in June 833 the unity of this monastic bastion was broken, as a direct consequence of Wala's involvement in the rebellions against the emperor. Corvey got an abbot of its own, the loyal Frankish aristocrat Warin, one of Radbert's former pupils and the first dedicatee of his well-known treatise on the Eucharist. Furthermore, the separation also meant that Corbie lost the control of formerly joint property in Saxony. ${ }^{35}$ All this hurt deeply, and the traces thereof are visible in the Epitaphium's first book. This was not aimed exclusively at the monks of Corvey, but Radbert mentions the younger monks of Corvey explicitly as part of his intended audience. These Saxon brethren needed a wake-up call: they had exchanged an excellent abbot for their present man in charge, the puffed-up Warin. ${ }^{36}$ The fraught relations with Corvey since the separation of 833 explains why the story of its foundation and Wala's prominent part in this has such a central place in the Epitaphium's first book. Given Wala's leadership of the first rebellion, many held him responsible for the break-up: the entire community of Corbie suffered from its abbot having incurred the emperor's wrath.

All of Radbert's Epitaphium is a valiant attempt to restore Wala's tarnished reputation in the eyes of his own monks as well as an exclusive audience of powerful outsiders. The first book, however, also targets a more specific audience, that is, the monks of Corvey who had not known their excellent abbot and now should learn all about him. This is surely the main reason why so much is made of Wala's connections with Saxony. He was a member of the Saxon nation, ${ }^{37}$ so Saxony was his fatherland (patria).$^{38}$ He would have preferred to wear Saxon native attire all the time, but his brother, Abbot Adalhard, forbade it. ${ }^{39}$ So at an assembly near Corvey Wala was dressed as a monk, but the unruly Saxons present recognized him as the charismatic magnate he really was, and were easily controlled..$^{40}$ Outside the Epitaphium, however, there is nothing particularly Saxon about Wala. He may figure in a list of Saxon hostages of 805/06, yet if so,

35 Krüger, 'Zur Nachfolgeregelung', especially pp. 189-95; Krüger, Studien, pp. 74-76, 101-15, 203-19.

36 Paschasius Radbertus, Epitaphium Arsenii, ed. by Dümmler, I.20, p. 49; De Jong, Epitaph for an Era, p. 51.

37 Paschasius Radbertus, Epitaphium Arsenii, ed. by Dümmler, I.12, p. 40; also I.13, p. 42.

38 Paschasius Radbertus, Epitaphium Arsenii, ed. by Dümmler, I.15, p. 45. On the historiography of the Saxon conquest and conversion, see two recent monographs: Flierman, Saxon Identities, and Rembold, Conquest and Christianisation, with references to older literature.

39 Paschasius Radbertus, Epitaphium Arsenii, ed. by Dümmler, I.16, p. 46.

40 Paschasius Radbertus, Epitaphium Arsenii, ed. by Dümmler, I.16, p. 45. 
it is in his capacity as one of their Frankish guardians. ${ }^{41}$ In the Royal Frankish Annals of 811 'count Wala son of Bernard' heads another list, namely of twelve men of the first rank (primores) from the gens Francorum who negotiated with Hemming and his Danes. ${ }^{42}$

It is no coincidence that Wala's Saxon identity is stressed in connection with Radbert's audience in Corvey. He broaches the topic by having the youngest member of the confabulation in the Epitaphium quiz the narrator, Pascasius:

I would like you to talk about the manner of his life under our Antony [Adalhard], for the particular benefit of our brothers living in Saxony, whose nation he belonged to, so that they might know more fully what sort of men they had as the founders of their faith. ${ }^{43}$

Historians, including myself, have assumed that Adalhard had a Frankish mother and Wala a Saxon one, combining two separate statements in the Vita Adalhardi and the Epitaphium Arsenii, neither of which mentions the mother of either half-brother: all that is said is that Adalhard was born from a lineage the most eminent Franks, ${ }^{44}$ while Wala was from a genus that hailed from Saxonia.

In both texts, however, ethnicity is a situational construct. Ethnic identity is invoked in an appropriate context, and then dropped again. Whereas in 826 Adalhard's illustrious Frankishness was an asset, some ten years later it was Wala's Saxon identity that counted, because of Radbert's audience in Corvey. This does not explain the absence of any Frankish identification, however. For this the narrative of the Epitaphium's first book offers ample opportunity, for example at the beginning where Wala is depicted as a youth at Charlemagne's court, or in the later section on his exploits in Italy as Lothar's deputy in the mid-820s. Here he is the intrepid dispenser of justice in a devious world full of hardened criminals, such as the perfidious men who had robbed a defenceless widow of her possessions. Wala pursues these culprits in Italy according to the highest principles of Carolingian justice, but unlike the Saxon context just discussed, this Italian setting renders ethnic identification irrelevant. What matters is that the great man fought corruption relentlessly, and unerringly discovered the truth, despite all efforts to hide it.

41 McKitterick, Charlemagne, pp. 106-07; Kosto, Hostages, pp. 66-67; Nelson, 'Charlemagne and Empire', pp. 223-28; Rembold, Conquest, pp. 54-61.

42 Annales regni Francorum, ed. by Kurze, s.a. 811, p. 134; Weinrich, Wala, p. 23.

43 Paschasius Radbertus, Epitaphium Arsenii, ed. by Dümmler, I.12, p. 40: 'Novimus haec omnia, sed quomodo conversatus sit sub Antonio nostro velim edicas, maxime pro fratribus nostris Saxonia degentibus, quorum fuit ex genere, ut sciant ad plenum quales habuerint fidei suae fundatores'.

${ }^{44}$ Paschasius Radbertus, Vita Adalhardi, ed. by Migne, 56, col. 1537A. 


\section{The World of Ambrose: The Epitaphium's Second Book}

The young Wala in Charlemagne's palace is depicted as a novice in the monastery, tested by 'Augustus' like gold in a furnace, and surmounting the trials and challenges of this alien and dangerous world. ${ }^{45}$ Radbert claims that the young man quickly rose to a position similar to Joseph, which not only highlights his position as second only to Caesar, but also implicitly puts the Carolingian palace on a par with that of Pharaoh. ${ }^{46}$ The boundaries between cloister and court are blurred, and Wala's abrupt change of status in 814 is obfuscated. From the most powerful lay magnate in Charlemagne's entourage, the first signatory of the old emperor's will, ${ }^{47}$ upon Louis's accession he became a member of his brother's community of Corbie, while Adalhard was despatched to a monastery on Noirmoutier, an island in the Atlantic Ocean off the mouth of the Loire. Most likely Wala entered Corbie not as a professed monk but as a monastic exile with a clerical status, yet all this is invisible in Radbert's narrative in the first book, which has one overarching purpose, namely to convince his audience of Arsenius's perfection as a monk and an abbot. I have suggested that this was also a matter of the author pleading his own cause, for Radbert had been Wala's deputy and may have been an abbot-in-waiting who still had ambitions in this respect once his beloved master had died. ${ }^{48}$ However, he only made it to the abbacy of Corbie in the winter of 843-44, and managed to hold on to this high office for seven years; sometime between the spring of 849 and April 853 he had to relinquish the abbacy because of multiple conflicts and pressures, both from Charles the Bald's court and adversarial monks in own community. ${ }^{49}$

Only after Radbert's deposition the second book was added. Its chronology is more straightforward than that of its predecessor: it opens with Wala in a central role at the crisis meeting in Aachen, called by Louis and Lothar in the winter of 828/29, and ends with his death in Bobbio in August 836. In between, there is the narrative of the two rebellions against Louis, with the first

45 Paschasius Radbertus, Epitaphium Arsenii, ed. by Dümmler, I.6, p. 29; Regula Benedicti, ed. and trans. by Venarde, 1.6, p. 16. On Wala (or rather Radbert) as a Benedictine abbot, see Mayr-Harting, 'Two Abbots in Politics'. On Charlemagne's court: Nelson, 'Was Charlemagne's Court a Courtly Society?'.

46 Paschasius Radbertus, Epitaphium Arsenii, ed. by Dümmler, I.6, p. 29: 'constituitur ab augusto echonomus totius domus, et venerabatur passim secundus a cesare, quasi putares alium Ioseph sceptra regni movere.' On the Pharaoh in monastic narratives, see Kramer, “....quia cor regis”.

${ }^{47}$ Einhard, Vita Karoli, ed. by Holder-Egger, 33, pp. 37-41. Innes, 'Charlemagne’s Will'.

48 De Jong, Epitaph for an Era, pp. 45-48.

${ }^{49}$ De Jong, Epitaph for an Era, pp. 42-43, 65-68. 
revolt of 830 and Wala's subsequent exile receiving most attention and space. The two key messages conveyed by the second book are, first, that despite appearances to the contrary, Wala was not disloyal to his emperor, and second, that had Louis and his co-emperor Lothar listened to his advice, the empire would not be in such a dismal state as it was 'nowadays' (hodie). It is a retrospective prophecy written from the perspective of the mid-850s, if not later, and much more outspoken and polemical than the first book. Radbert's focus now shifted from Corbie and Corvey to the palace and the empire at large. There is much discussion of the needs of the respublica that is entirely absent in the first book..$^{50}$ Conversely, ethnic identification is absent, even though there is an intriguing passage about Wala's connection through his earlier marriage with his chief adversary, Bernard of Septimania. Yet it is about family bonds and the anguish of seeing them broken through political strife; Frankish or Saxon identity does not come into it. ${ }^{51}$

The Epitaphium was a work planned to comprise two books, following its main model, Ambrose's funeral oration for his brother Satyrus. ${ }^{52}$ Although this provides the overall framework for Radbert's text, citations and paraphrases of Ambrose's epitaph mainly figure at the beginning of the first and the end of the second book. At the heart of the work, covering the majority of the second book, is Wala in his guise as Jeremiah, speaking truth to power. ${ }^{53}$ This power is located in Louis's palace, and then undermined and disordered by the emperor's godson Bernard of Septimania, who was appointed chamberlain in August 829. He was a military hero who had earned his reputation in Barcelona in 827, and was meant to be a new broom who could be Louis's loyal bastion because he was the emperor's godson. Soon, he incurred the enmity of all those he had elbowed out, and became Louis's main hazard..$^{54}$ As is well known and does not need to be rehearsed here, the courtiers who had been elbowed out by his sudden arrival retaliated by accusing Bernard of adultery and even incest with Louis's wife Judith..$^{55}$ The sacred palace (sacrum palatium) had been turned into

50 De Jong, 'The Two Republics'; De Jong, 'For God, King and Country'.

${ }^{51}$ Paschasius Radbertus, Epitaphium Arsenii, ed. by Dümmler, II.8, p. 69; De Jong, Epitaph for an Era, pp. 154-55. My initial interpretation was that the sister who married Wala was William of Gellone's and not his son Bernard's, but I have come to see this differently; see Confronting Crisis, p. 22 n. 61.

52 For a provisional list of citations and paraphrases, see Von Moos, Consolatio, II, 100-01.

53 De Jong, 'Becoming Jeremiah'; De Jong, Epitaph for an Era, pp. 125-29.

${ }^{54}$ De Jong, Penitential State, pp. 41-43; Depreux, 'Der karolingische Hof'; De Jong, Epitaph for an Era, pp. 151-59.

55 De Jong, Penitential State, pp. 185-213; Dohmen, Ursache, pp. 109-76. 
a brothel by the empress and her lover, which became the public legitimation of what historians have called the 'loyal palace rebellion', an entirely appropriate label if one swallows Radbert's arguments in the Epitaphium's second book hook, line, and sinker. The Carolingian palace was a competitive place, and lack of loyalty was the main and mutual accusation of those struggling for position and precedence.

In his second book Radbert attacked those who had turned a once peaceful palace upside down, with constant reference to the Christian imperial court of Theodosius the Great (r. 379-95) and Valentinian I (r. 364-75). His point of departure was Wala's nickname, Arsenius. ${ }^{56}$ According to late antique and early medieval monastic tradition, Arsenius had been a courtier to Theodosius and the tutor of the emperor's two sons Arcadius and Honorius. Wala was called Arsenius throughout the entire Epitaphium, but outside this text, this was also his nickname, just as his brother Adalhard had been called Antony, and Radbert was called Paschasius. Whether these were names for daily use we do not know, but they figured in letters and literary production. 'Arsenius', however, was at the centre of an eclectic web of aliases which, as far as I can see now, was entirely intra-textual. There is no evidence that Lothar was ever called Honorius in any other communication, and the same holds true for Justina (Judith), Justinian (Louis the Pious), or Gratian (Louis the German). The strongest connection in the web is the one between Lothar/Honorius and his older mentor Wala/ Arsenius. The historical Honorius (r. 393-423) was Theodosius's younger son, who was made co-emperor in 393. The Honorius of the Epitaphium voices Arsenius's ideals of good governance, confronting his father with the values he had learned at the latter's court, but which had been sadly ignored:

This I have always heard in your sacred assembly, and in the senate of most illustrious men; this I have always observed in your deeds; this I have learned from you; this we read about in the accounts of the deeds of the ancients: that valiant and pre-eminent, and well-deserving men should be honoured and covered in glory, rather than driven away. ${ }^{57}$

Having witnessed the goings on in his step-mother's sinful palace, Gratian/ Louis the German has lurid tales to tell on the eve of the first rebellion of 830 . It was Bernard's plan to murder Louis and overthrow the entire imperial rule,

${ }^{56}$ For what follows, I rely on De Jong, Epitaph for an Era, pp. 132-48.

57 Paschasius Radbertus, Epitaphium Arsenii, ed. by Dümmler, II.17, p. 87: 'Hoc semper audivi in vestro sacro concilio, et in clarissimorum senatu virorum, hoc semper in vestris recognovi factis, hoc a vobis audivi, hoc legimus in gestis antiquorum, fortes viros et clarissimos, ac bene meritos honorari magis debere, et gloria illustrari quam depelli'. 
and all this had been planned and plotted with the aid of divination, augury, and all of the dark arts. ${ }^{58}$

The alias 'Gratian' is dependent on Radbert's more central choice of Judith's byname. Justina was the second wife of Emperor Valentinian I (364-75), who in 385/86 unleashed an infamous campaign against Bishop Ambrose of Milan. ${ }^{59}$ Her bad reputation in Christian historiography originates with a letter from Ambrose himself, which cites Elijah and John the Baptist as the victims of wilful women who dominated their husbands and tempted them to do evil. ${ }^{60}$ Naming Judith 'Justina' meant revealing the empress as the instigator of her husband's misguided choices; it also moved Ambrose more to the foreground, even though the bishop of Milan was never named in the Epitaphium's second book as the victim of Justina's persecution, nor as Theodosius's trenchant critic who made the emperor perform a public penance in 392. Yet his presence makes itself felt throughout the text, and even more so because Louis is not deigned worthy of the honorific alias of Theodosius. ${ }^{61}$ Instead, as 'Justinian' Radbert turns the hapless son of Charlemagne into a non-Theodosius, possibly in reaction to authors such as his contemporary, Louis's biographer known as the Astronomer. Writing shortly after Louis's death in 840 , this courtier-biographer had made the most of Theodosius's penance in the context of Louis's public atonement in Attigny in $822 .{ }^{62}$ According to the Astronomer, elaborating on the Royal Frankish Annals, this atonement had also served to make amends for what Louis had done to Adalhard and Wala, but Radbert would have none of it. For him, Louis was Justinian, with both positive and negative connotations I have explored elsewhere, ${ }^{63}$ but with the prevailing and quite literal implication that this emperor belonged to Justina and did her bidding.

58 Paschasius Radbertus, Epitaphium Arsenii, ed. by Dümmler, II.9, p. 72: 'Ad ultimum vero de nece patris et de totius imperii edixit subversione, qualiter auspiciis, auguriis, consiliis, atque insidiis, necnon et omnibus malignis artibus esset prefixum'.

59 On the historical context, see McLynn, Ambrose, pp. 170-71, and the introduction to the chapter 'Ambrose's Conflict with the Empress Justina at Milan', by Liebeschuetz in Ambrose of Milan, Epistolae, trans. by Liebeschuetz, pp. 124-36.

${ }^{60}$ Ambrose of Milan, Epistolae, trans. by Liebeschuetz, 76[20].12, 18, pp. 160-73. On Justina's reputation and Radbert's use of this to vilify Judith, see De Jong, Epitaph for an Era, pp. 138-39.

${ }^{61}$ On Theodosius as a model for ninth-century rulership, see Ward, 'Lessons in Leadership' with references to older literature.

62 De Jong, Penitential State, pp. 122-31.

${ }^{63}$ De Jong, Epitaph for an Era, pp. 139-44. 
Radbert's aliases were associative and eclectic, and by no means confined to this loosely connected world of Ambrose. Naso (Ovid) for Bernard of Septimania came from classical literature. It meant to evoke associations with Ovid's adultery and exile, and possibly also with the daringly immoral nature of his poetry. Then there was a biblical alias, Phassur, for Archbishop Ebo of Reims, who had jailed Jeremiah, like Ebo had exiled Wala. Finally, there is the still elusive alias Melanius for Pippin of Aquitaine, Louis's middle son, which may or not come from the classical repertoire. Be this as it may, Phassur and Melanius are merely supporting roles.$^{64}$ In the text itself the prominent figures are Arsenius and Honorius, allied in their battle against Justina and her associates; at the background, there is Ambrose speaking truth to power, as Wala did, and Louis who is deemed too weak to be anything like Theodosius.

In recent discussions about the possible auctor intellectualis of the PseudoIsidorian Decretals, it has been suggested that Radbert's love of nicknames, bynames, aliases, and pseudonyms show him to have the mind-set of a dissembler required to pull off such a major forgery. ${ }^{65}$ This is not what the use of such names in the Epitaphium is all about. In his treatise Cogitis me, written for the nuns of Nôtre-Dame of Soissons who had educated him as a child, Radbert wrote this meditation on the Assumption of the Virgin as 'Jerome', calling it a 'letter from the Blessed Jerome to Paula and Eustochium', addressing the nuns of Soissons with the names of Jerome's patroness and correspondent Paula and her daughter. Assuming an alias of this kind did imply posturing as Jerome but honouring one of the greatest authors of an authoritative Christian past, who had become a household name in the Carolingian elite. ${ }^{66}$ Biblical commentary that made the works of the patres accessible was what kings and queens commissioned from the likes of Hrabanus Maurus and Radbert. ${ }^{67}$ As for the naming and shaming in the Epitaphium's second book, this assumed a common ground of knowledge of the imperial Christian past in which heroes such as Ambrose had flourished, and provided examples for posterity. In the mid-850s, when Radbert wrote his second book, this landscape of authority was still fluid. Some biblical books such as Judith and Maccabees only became canonical in the course of the ninth century, because of Hrabanus's wide-ranging and systematic exegesis. Hincmar's many writings of the 850 s and 860 s not only addressed acute political problems but

${ }^{64}$ De Jong, Epitaph for an Era, pp. 144-45.

${ }^{65}$ Zechiel-Eckes, Fälschung. For the distinction between nicknames and aliases or pseudonyms, see De Jong, Epitaph for an Era, pp. 132-36.

${ }^{66}$ Ripberger, Pseudo-Hieronymus-Brief.

${ }^{67}$ De Jong, 'Empire as ecclesia'. 
also selected and propagated a corpus of biblical and patristic texts for future reference, adding to a growing certainty of what was canonical and what was not. ${ }^{68} \mathrm{But}$ this was still contested at the time, which was why 'Pseudo-Isidore' could join the contestation and enter mainstream debates about canonicity.

One of Radbert's key sources for the world of Ambrose was the Historia ecclesiastica tripartita, a translation and editorial selection from three fifth-century Greek histories by Socrates, Sozomen, and Theodoret, made by Epiphanius and commissioned by Cassiodorus. ${ }^{69}$ As Zechiel-Eckes discovered, the Corbie copy of the Historia tripartita of Cassiodorus/Epiphanes was systematically excerpted by whoever put together an early version of the False Decretals. ${ }^{70}$ In passing, Zechiel-Eckes observed that Radbert's naming strategy was an imaginative projection of the concerns and tensions of the present into Christian Late Antiquity. This 'antikisierende Rückprojektion' reminded him of the Pseudo-Isidorian Decretals, which also used late antique Christian historiography in order to integrate past canonical texts, forged and real, into the ninthcentury present. ${ }^{71}$ Even though it contributes less than Zechiel-Eckes thought towards identifying Radbert as Pseudo-Isidore himself, it is a perceptive remark which should be kept in mind in further research. ${ }^{72}$ By now, when three out of four early manuscripts of the so-called False Decretals seem to originate from Corbie, ${ }^{73}$ it would be counterintuitive to deny the connection with Radbert, who was, after all, the abbot of this monastery between 843 and $849 / 53$. Yet all the evidence points to the early 850 s as the period in which this mixture of authentic and forged canonical texts was launched. It is difficult to imagine that this happened without the knowledge of Corbie's abbot.

${ }^{68}$ For an excellent recent analysis of Hincmar's methods, see Stone and West, trans. and ann., Divorce of King Lothar, cited under Primary Sources as Divorce of King Lothar.

${ }^{69}$ St Petersburg, NLR, MS Lat. F v I 11; Jacob and Hanslik, Die handschriftliche Überlieferung, pp. 10-11. On the Historia tripartita in Corbie, see Ganz, Corbie, p. 143; ZechielEckes, 'Ein Blick in Pseudo-Isidors Werkstatt'; on the ninth-century history of the work, see McKitterick, History and Memory, pp. 233-34; Scholten, 'Cassiodorus' Historia tripartita'.

70 The two key articles are Zechiel-Eckes, 'Ein Blick in Pseudo-Isidors Werkstatt' and 'Auf Pseudoisidors Spur'; the most complete recent discussion of ongoing research is offered by Ubl and Ziemann, eds, Fälschung als Mittel der Politik?

${ }^{71}$ Zechiel-Eckes, 'Ein Blick in Pseudo-Isidors Werkstatt', p. 59; see the comments of De Jong, 'Paschasius Radbertus and Pseudo-Isidore', pp. 171-72.

72 See De Jong, Epitaph for an Era, pp. 199-205 for an overview of the status quaestionis.

${ }^{73}$ Most recently on this issue: Knibbs, 'Pseudo-Isidore's Ennodius'; see also Knibbs, 'Ebo of Reims', and Ubl and Ziemann, eds, Fälschung als Mittel der Politik? 
The False Decretals, a massive and sprawling collection ascribed to 'PseudoIsidore' is another witness to the presence of the 'world of Ambrose' in the minds of articulate authors in mid-ninth-century West Francia. The memory of the bishop of Milan who intrepidly made Theodosius perform a public penance was of paramount importance to all those eager to give churchmen some clout in their competition with formidable royal religious authority. ${ }^{74}$ The death of Louis the Pious in 840 and the ensuing struggle for succession had concentrated minds, so to speak, and yielded some exceptionally articulate reflections on the recent past, including the second book of the Epitaphium Arsenii. As Reimitz said, the tension between Frankish and Christian empire was never entirely resolved, ${ }^{75}$ yet it is clear that in the 850 s, when he added his polemical sequel to his epitaph for Wala, Frankish pride was no longer part of Radbert's strategies of persuasion. The mirror he held up to his contemporaries was inspired by late antique historiography and exegesis. It was a vision of community that was very different from that of the Vita Adalhardi, written when he was still a young and ambitious member of his community with good prospects, and also different from the first book of the Epitaphium which pictures Wala as a perfect abbot with a Saxon identity nobody could fault. But then there is the second book, in a world turned upside down by the rebellions and the so-called fraternal wars of 840-43. It is then that Radbert turned to the world of Ambrose that was omnipresent in late antique Christian historiography. This was indeed an attempt to anchor a shaky present in an authoritative past. Yet it was not just any past: choices were made, with reference to what might appeal to contemporary audiences. By the mid-850s, strident statements on Frankish superiority were no longer required. By now it was the loss of a joint and unified imperial rule that was deplored, and remembered all the more in terms of a political community imagined through the prism of late antique imperial Christianity. ${ }^{76}$

${ }^{74}$ Booker, Past Convictions takes a long-term perspective on the ninth-century narratives; see also De Jong, Penitential State, pp. 59-111.

${ }^{75}$ Reimitz, History, p. 454.

${ }^{76}$ Not to be confused with the territorial unity of the Carolingian Empire; see Patzold, 'Eine "loyale Palastrebellion"'; Patzold, “"Einheit” versus "Fraktionierung”'. 


\section{Works Cited}

\section{Manuscripts}

Paris, Bibliothèque nationale de France, MS fonds latin 13909

—, MS fonds latin 18296

St Petersburg, National Library of Russia, MS Lat. F v I 11

\section{Primary Sources}

Agobard of Lyon, Adversus legem Gundobadi, ed. by Ernst Dümmler, in Monumenta Germaniae Historica: Epistolae, 5, Epistolae Karolini aevi, 3 (Berlin: Weidmann, 1899), pp. 158-64

—, Adversus legem Gundobadi, ed. by Lieven van Acker, in Opera omnia, Corpus christianorum continuatio medievalis, 52 (Turnhout: Brepols, 1981), pp. 19-28

Ambrose of Milan, Political Letters and Speeches, trans. and introduction by John H. G. W. Liebeschuetz with Carole Hill, Translated Texts for Historians, 43 (Liverpool: Liverpool University Press, 2005)

Astronomer, Vita Hludowici imperatoris, ed. by Ernst Tremp, in Monumenta Germaniae Historica: Scriptores rerum Germanicarum in usum scholarum separatim editi, 64 (Hanover: Hahn, 1995), pp. 278-555

Confronting Crisis in the Carolingian Empire: Paschasius Radbertus' Funeral Oration for Wala of Corbie, trans. and annotated by Mayke de Jong and Justin Lake, Manchester Medieval Sources Series (Manchester: Manchester University Press, 2020)

The Divorce of King Lothar and Queen Theutberga: Hincmar of Rheims's 'De divortio', trans. and annotated by Rachel Stone and Charles West, Manchester Medieval Sources Series (Manchester: Manchester University Press, 2016)

Hrabanus Maurus, Liber de oblatione puerorum, in Patrologiae cursus completus: series latina, ed. by Jacques-Paul Migne, 221 vols (Paris, 1844-64), cvir (1864), cols 419-40

Paschasius Radbertus, Vita S. Adalhardi, in Acta sanctorum Ordinis Sancti Benedicti, ed. by Dom Jean Mabillon, IV.1 (Paris, 1677), pp. 308-44

- Vita Adalhardi, in Patrologiae cursus completus: series latina, ed. by Jacques-Paul Migne, 221 vols (Paris, 1844-64), cxx (1864), cols 1507-82

— Epitaphium Arsenii, ed. by Ernst Dümmler, in Abhandlungen der Königlichen Akademie der Wissenschaften zu Berlin, Philosophisch-Historische Abhandlungen, 2 (Berlin: Reimer, 1900), pp. 1-98

—, Epistola ad Odilmannum, ed. by Ernst Dümmler, in Monumenta Germaniae Historica: Epistolae, 6, Epistolae Karolini aevi, 4 (Berlin: Weidmann, 1925), no. 5, pp. 136-37

—, Expositio in Matheo libri XII, ed. by Paul Bede, Corpus christianorum continuatio medievalis, 56, 3 vols (Turnhout: Brepols, 1984)

Vita Karoli Magni, ed. by Oswald Holder-Egger, Monumenta Germaniae Historica: Scriptores rerum Germanicarum in usum scholarum separatim editi, 25 (Hanover: Hahn, 1913) 


\section{Secondary Studies}

Berschin, Walter, Biographie und Epochenstil im lateinischen Mittelalter, III: Karolingische Biographie: 750-920 n. Chr., Quellen und Untersuchungen zur lateinischen Philologie des Mittelalters, 10 (Stuttgart: Hiersemann, 1991)

Bischoff, Bernhard, Katalog der festländischen Handschriften des neunten Jabrbunderts (mit Ausnabme der wisigotischen), III: Padua-Zwickau, ed. by Birgit Ebersperger (Wiesbaden: Harrassowitz, 2014)

Booker, Courtney M., Past Convictions: The Penance of Louis the Pious and the Decline of the Carolingians (Philadelphia: University of Pennsylvania Press, 2009)

- , 'Hypocrisy, Performativity and the Carolingian Pursuit of Truth', Early Medieval Europe, 26 (2019), 174-202

Depreux, Philippe, 'Der karolingische Hof als Institution und Personenverband', in Le Corti nell'Alto Medioevo, I, Settimane di Studio del Centro Italiano di Studi sull'Alto Medioevo, 62 (Spoleto: Fondazione CISAM, 2015), pp. 137-64

— , 'The Penance of Attigny (822) and the Leadership of the Bishops in Amending Frankish Society', in Religious Franks: Religion and Power in the Frankish Kingdoms, ed. by Rob Meens and others (Manchester: Manchester University Press, 2016), pp. 370-85

Dohmen, Linda, Die Ursache alles Übels: Untersuchungen zu den Unzuchtsvorwürfen gegen die Gemahlinnen der Karolinger, Mittelalter-Forschungen, 53 (Ostfildern: Thorbecke, 2017)

Flierman, Robert, Saxon Identities, AD 150-900 (London: Bloomsbury Academic, 2017) Ganz, David, Corbie in the Carolingian Renaissance, Beihefte der Francia, 20 (Sigmaringen: Thorbecke, 1990)

—, 'The Epitaphium Arsenii and Opposition to Louis the Pious', in Charlemagne's Heir: New Perspectives on the Reign of Louis the Pious (814-40), ed. by Peter Godman and Roger Collins (London: Clarendon, 1990), pp. 537-50

—, 'The Astronomer's Life of Louis the Pious', in Rome and Religion in the Medieval World: Studies in Honor of Thomas F. X. Noble, ed. by Valerie Garver and Owen McPhelan (Farnham: Taylor \& Francis, 2014), pp. 129-48

Innes, Matthew, 'Charlemagne's Will: Inheritance, Ideology and the Imperial Succession', English Historical Review, 112 (1997), 833-55

__ '“A Place of Discipline": Carolingian Courts and Aristocratic Youth', in Court Culture in the Early Middle Ages: The Proceedings of the First Alcuin Conference, ed. by Catherine Cubitt, Studies in the Early Middle Ages, 3 (Turnhout: Brepols, 2003), pp. 59-76

Jacob, Walter, and Rudolf Hanslik, Die handschriftliche Überlieferung der sogenannten 'Historia tripartita' des Epiphanius-Cassiodor, Texte und Untersuchungen zur Geschichte der altchristlichen Literatur, 59 (Berlin: Akademie Verlag, 1954)

Jong, Mayke de, 'The Empire as ecclesia: Hrabanus Maurus and Biblical historia for Rulers', in The Uses of the Past in the Early Middle Ages, ed. by Yitzhak Hen and Matthew Innes (Cambridge: Cambridge University Press, 2000), pp. 191-226

_ , 'Sacrum palatium et ecclesia: l'autorité religieuse royale sous les Carolingiens (790-840)', Annales: histoire, sciences sociales, 58 (2003), 1243-69 
- The Penitential State: Authority and Atonement in the Age of Louis the Pious, 814-40 (Cambridge: Cambridge University Press, 2009)

— - 'The State of the Church: Ecclesia and Early Medieval State Formation', in Der frühmittelalterliche Staat: Europäische Perspektive, ed. by Walter Pohl and Veronika Wieser, Forschungen zur Geschichte des Mittelalters, 16 (Vienna: Verlag der Österreichischen Akademie der Wissenschaften, 2009), pp. 241-55

, 'Becoming Jeremiah: Paschasius Radbertus on Wala, Himself and Others', in Ego Trouble: Authors and their Identities in the Early Middle Ages, ed. by Richard Corradini and others, Forschungen zur Geschichte des Mittelalters, 15 (Vienna: Österreichische Akademie der Wissenschaften, 2010), pp. 185-96

, 'Paschasius Radbertus and Pseudo-Isidore: The Evidence of the Epitaphium Arsenii', in Rome and Religion in the Medieval World: Studies in Honor of Thomas F.X. Noble, ed. by Valerie Garver and Owen McPhelan (Farnham: Taylor \& Francis, 2014), pp. 149-78

— , 'For God, King and Country: The Personal and the Public in the Epitaphium Arsenii, Early Medieval Europe, 25 (2017), 102-13

- 'The Resources of the Past: Paschasius Radbertus and his Epitaphium Arsenii, in Exzerpieren - Kompilieren - Tradieren: Transformationen des Wissens zwischen Spätantike und Frühmittelalter, ed. by Stephan Dusil, Gerald Schwedler, and Raphael Schwitter, Millennium-Studien, 64 (Berlin: de Gruyter, 2017), pp. 131-51

— ' 'The Two Republics: Ecclesia and the Public Domain in the Carolingian World', in Italy and Early Medieval Europe: Essays Presented to Chris Wickham, ed. by Ross Balzaretti, Julia Barrow, and Patricia Skinner (Oxford: Oxford University Press, 2018), pp. 486-500

- Epitaph for an Era: Politics and Rhetoric in the Carolingian World (Cambridge: Cambridge University Press, 2019)

Kasten, Brigitte, Adalhard von Corbie: Die Biographie eines karolingischen Politikers und Klostervorstehers, Studia humaniora, 3 (Düsseldorf: Droste, 1986)

Kempshall, Matthew, Rhetoric and the Writing of History, 400-1500 (Oxford: Oxford University Press, 2011)

Knibbs, Eric, 'Ebo of Reims, Pseudo-Isidore, and the Date of the False Decretals', Speculum, 92 (2017), 145-83

— , 'Pseudo-Isidore's Ennodius', Deutsches Archiv für Erforschung des Mittelalters, 74 (2018), 1-51

Kosto, Adam J., Hostages in the Middle Ages (Oxford: Oxford University Press, 2012)

Kramer, Rutger, “....quia cor regis in manu Dei est”: The Pharaoh in Carolingian Monastic Narratives', in Compétition et sacré au haut moyen âge: entre médiation et exclusion, ed. by Philippe Depreux, François Bougard, and Régine Le Jan, Collection haut moyen âge, 21 (Turnhout: Brepols, 2015), pp. 137-61

-, Rethinking Authority in the Carolingian Empire: Ideals and Expectations during the Reign of Louis the Pious (813-28) (Amsterdam: Amsterdam University Press, 2019)

Krüger, Karl Heinz, 'Zur Nachfolgeregelung von 826 in den Klöstern Corbie und Corvey', in Tradition als historische Kraft: Interdisziplinäre Forschungen zur Geschichte des früheren Mittelalters, ed. by Norbert Kamp and Joachim Wollasch (Berlin: de Gruyter, 1982), pp. 181-96 
—_, Studien zur Corveyer Gründungsüberlieferung (Münster: Aschendorff, 2001)

Mayr-Harting, Henry, 'Two Abbots in Politics: Wala of Corbie and Bernard of Clairvaux', Transactions of the Royal Historical Society, 5 th ser., 40 (1989), 217-37

McKitterick, Rosamond, History and Memory in the Carolingian World (Cambridge: Cambridge University Press, 2004)

- Charlemagne: The Formation of a European Identity (Cambridge: Cambridge University Press, 2008)

McLynn, Neil, Ambrose of Milan: Church and Court in a Christian Capital (Berkeley: University of California Press, 1994)

Moos, Peter von, Consolatio: Studien zur mittelalterlichen Trostliteratur über den Tod und zum Problem der christlichen Trauer, I: Darstellungsband, and II: Anmerkungsband, Münstersche Mittelalter-Schriften, 3.1-2 (Munich: Fink, 1971)

Nahmer, Dieter von der, 'Der Bibel im Adalhardsvita des Radberts von Corbie', Studi medievali, 3rd ser., 23 (1982), 15-83

Nelson, Janet L., 'The Search for Peace at a Time of War: The Carolingian Brüderkrieg', in Träger und Instrumentarien des Friedens im hohen und späten Mittelalters, ed. by Johannes Fried, Vorträge und Forschungen vom Konstanzer Arbeitskreis für mittelalterliche Geschichte, 43 (Sigmaringen: Thorbecke, 1996), pp. 87-114

— , 'Making a Difference in Eighth-Century Politics: The Daughters of Desiderius', in After Rome's Fall: Narrators and Sources of Early Medieval History, ed. by Alexander C. Murray (Toronto: University of Toronto Press, 1998), pp. 171-90

—, 'Was Charlemagne's Court a Courtly Society?', in Court Culture in the Early Middle Ages: The Proceedings of the First Alcuin Conference, ed. by Catherine Cubitt, Studies in the Early Middle Ages, 3 (Turnhout: Brepols, 2003), pp. 39-57

—. 'Charlemagne and Empire', in The Long Morning of Medieval Europe: New Directions in Early Medieval Studies, ed. by Jennifer R. Davis and Michael McCormick (Aldershot: Ashgate, 2008), pp. 223-34

Patzold, Steffen, 'Eine "loyale Palastrebellion" der "Reichseinheitspartei"? Zur "Divisio imperii" von 817 und zu den Ursachen des Aufstandes gegen Ludwig den Frommen im Jahre 830', Frümittelalterliche Studien, 40 (2006), 43-77

_- 'Hraban, Gottschalk und der Traktat De oblatione puerorum', in Raban Maur et son temps, ed. by Philippe Depreux and others, Haut Moyen Âge, 9 (Turnhout: Brepols, 2010), pp. 105-18

__ , "Einheit" versus "Fraktionierung": Zur symbolischen und institutionellen Integration des Frankenreichs im 8./9. Jahrhundert', in Visions of Community: Community in the PostRoman World: The West, Byzantium and the Islamic World, 300-1100, ed. by Walter Pohl, Clemens Gantner, and Richard Payne (Farnham: Ashgate, 2012), pp. 375-90

—_, Gefälschtes Recht aus dem Frühmittelalter: Untersuchungen zur Herstellung und Überlieferung der pseudoisidorischen Dekretalen (Heidelberg: Winter, 2015)

Pohl, Walter, 'Introduction: Strategies of Identification: A Methodological Profile', in Strategies of Identification: Ethnicity and Religion in Early Medieval Europe, ed. by Walter Pohl and Gerda Heydemann, Cultural Encounters in Late Antiquity and the Middle Ages, 13 (Turnhout: Brepols, 2013), pp. 1-64 
_ , 'Creating Cultural Resources for Carolingian Rule: Historians of the Christian Empire', in The Resources of the Past in Early Medieval Europe, ed. by Clemens Gantner, Rosamond McKitterick, and Sven Meeder (Cambridge: Cambridge University Press, 2015), pp. 15-33

Reimitz, Helmut, 'Nomen Francorum obscuratum: Zur Krise der fränkischen Identität zwischen der kurzen und langen Geschichte der Annales regni Francorum', in Völker, Reiche, Namen im Mittelalter, ed. by Matthias Becher and Stephanie Dick (Paderborn: Fink, 2011), pp. 279-96

- History, Frankish Identity and the Framing of Western Ethnicity, 550-850 (Cambridge: Cambridge University Press, 2015)

Rembold, Ingrid, Conquest and Christianisation: Saxony and the Carolingian World, 772-888 (Cambridge: Cambridge University Press, 2017)

Renswoude, Irene van, 'License to Speak: The Rhetoric of Free Speech in Late Antiquity and the Early Middle Ages' (unpublished doctoral thesis, Utrecht University, 2011)

- The Rhetoric of Free Speech in Late Antiquity and the Early Middle Ages (Cambridge: Cambridge University Press, 2019)

Ripberger, Albert, Der Pseudo-Hieronymus-Brief IX 'Cogitis me': Ein erster marianischer Traktat des Mittelalters von Paschasius Radbertus, Spicilegium Friburgense, 9 (Freiburg: Universitätsverlag Freiburg, 1962)

Scholten, Désirée, 'Cassiodorus' Historia tripartita before the Earliest Extant Manuscripts', in The Resources of the Past in the Early Middle Ages, ed. by Clemens Gantner, Rosamond McKitterick, and Sven Meeder (Cambridge: Cambridge University Press, 2015), pp. 34-50

Ubl, Karl, and Daniel Ziemann, eds, Fälschung als Mittel der Politik? Pseuodoisidor im Licht der neuen Forschung: Gedenkschrift für Klaus Zechiel-Eckes, Monumenta Germaniae Historica Studien und Texte, 57 (Wiesbaden: Harrassowitz, 2015)

Verri, Chiara, 'Il libro primo dell'Epitaphium Arsenii di Pascasio Radberto', Bulletino dell'Istituto Storico Italiano per il Medio Evo, 103 (2001/02), 33-131

_- 'L'arte di ritratto: la descrizione del santo nella Vita Adalhardi di Pascaso Radberto', in Amicorum societas: mélanges offerts à François Dolbeau pour son 65 e anniversaire, ed. by Jacques Elfassi, Cécile Lanéry, and Anne-Marie Turcan-Verkerk, Millennio medievale, 96, Strumenti e studi, 34 (Florence: SISMEL, 2013), pp. 635-56

Ward, Graeme, 'Lessons in Leadership: Constantine and Theodosius in Freculf of Lisieux's Histories', in The Resources of the Past in Early Medieval Europe, ed. by Clemens Gantner, Rosamond McKitterick, and Sven Meeder (Cambridge: Cambridge University Press, 2015), pp. 68-83

Weinrich, Lorenz, Wala: Graf, Mönch und Rebell: Die Biographie eines Karolingers, Historische Studien, 386 (Lübeck: Matthiesen, 1963)

Zechiel-Eckes, Klaus, 'Ein Blick in Pseudo-Isidors Werkstatt: Studien zum Entstehungsprozess der falschen Dekretalen; Mit einen exemplarischen editorischen Anhang, Francia, 28.1 (2001), 37-90

— , 'Auf Pseudoisidors Spur: Oder: Versuch, einen dichten Schleier zu lüften', in Fortschritt durch Fälschungen? Ursprung, Gestalt und Wirkungen der pseudoisi- 
dorischen Fälschungen, ed. by Wilfried Hartmann and Gerhard Schmitz, Monumenta Germaniae Historica Studien und Texte, 31 (Hanover: Hahn, 2002), pp. 1-28

—, Fälschung als Mittel politischer Auseinandersetzung: Ludwig der Fromme (814-40) und die Genese der pseudoisidorischen Dekretalen, Nordrhein-Westfälische Akademie der Wissenschaft und der Künste, Vorträge: Geisteswissenschaften, 428 (Paderborn: Schöningh, 2011) 